\title{
Secretory IgA specific for herpes simplex virus in lacrimal fluid from patients with herpes keratitis - a possible diagnostic parameter
}

\author{
'B. PEDERSEN, 'S. MøLlER ANDERSEN, ${ }^{2}$ A. KLAUBER, ${ }^{2}$ E. OTTOVAY, \\ ${ }^{3} \mathrm{~J}$. U. PRAUSE, 'CHEN ZHONG, AND ${ }^{1} B$. NORRILD \\ From the 'Institute of Medical Microbiology, University of Copenhagen, Juliana Mariesvej 22, \\ DK-2100 Copenhagen $Q$, Denmark; the ${ }^{2}$ Department of Eye Disease, Rigshospitalet, Blegdamsvej, \\ DK-2100 Copenhagen $Q$, Denmark; and the ${ }^{3}$ Eye Pathology Institute, University of Copenhagen, \\ Frederik d. V's vej 11, DK-2100 Copenhagen D, Denmark
}

SUMMARY In the present study a solid-phase radioimmune assay was used for the demonstration of herpes simplex virus-specific IgG and secretory $\operatorname{IgA}$ antibodies in the lacrimal fluid from patients with active recurrent herpes keratitis. The method was quantitative and made it possible to test specifically for the production of secretory $\operatorname{IgA}$ antibodies produced during an active herpes simplex virus infection. The production of secretory $\operatorname{IgA}$ was followed in 2 patients with fresh recurrent lesions. The HSV-specific secretory IgA could be demonstrated during the first 10 days of infection, where the maximal concentration was reached 3-5 days after the first symptoms occurred. The secretory antibodies were locally produced, and it is shown for the first time that herpes virus-specific secretory antibodies were of diagnostic value.

Herpes keratitis is the most frequent cause of corneal opacities in developed countries, and because of its tendency to recurrence the infection often causes irreversible damage, followed in severe cases by the development of blindness. ${ }^{1}$ Usually the diagnosis is based mainly on clinical evidence. However, herpes keratitis has various atypical manifestations which often makes it difficult to give an exact diagnosis.

The detection of antibodies reactive to HSV in the lacrimal fluid has mainly been done by the passive haemagglutination test (PHA), which allows the detection of antibodies of the IgG class. ${ }^{2} \mathrm{HSV}$-specific antibodies were found in $14.2 \%$ of the tear samples from patients with inflammatory diseases of nonherpetic aetiology. The PHA test did not allow a differentiation between locally produced antibodies reactive to HSV and serum antibodies transmitted to the lacrimal fluid by impairment of the blood vessels caused by inflammation.

Secretory $\operatorname{IgA}(\mathrm{SIgA})$ differs from IgA in serum both chemically and immunologically by the presence of a secretory component that is coiled around the $\mathrm{Fc}$ fragment of both IgA molecules of the dimer Correspondence and reprint request: Dr B. Norrild. structure. $^{3}$ The secretory antibodies are present mainly in external secretions. ${ }^{45}$

In the present study we used a radioimmune assay developed for the detection of SIgA reactive specifically with HSV. The presence of the virus-specific SIgA in lacrimal fluid from a limited number of patients with active herpes keratitis and from control persons was studied. The HSV-specific SIgA was found only in the lacrimal fluid from the patients, and the possible role of the test for the diagnosis of herpes simplex infections of the eye is discussed.

\section{Materials and methods}

PATIENTS AND CONTROLS

Seven patients and 7 controls were selected as follows. The 7 patients (nos. 1 to 7 ) suffered from different types of herpetic keratitis. In the case of recurrent herpetic keratitis tears were collected in the active phase-so-called fresh recurrency-when the epithelial defects were present. Between herpetic attacks these patients are inactive from a clinical point of view. Patient no. 4 had suffered from a first-time herpetic keratitis, but it had shown a prolonged 
Table 1A Patients

\begin{tabular}{|c|c|c|c|c|c|c|}
\hline \multicolumn{3}{|c|}{$\begin{array}{l}\text { Patient no., sex, } \\
\text { age (years) }\end{array}$} & \multirow{2}{*}{$\begin{array}{l}\text { Number of previous } \\
\text { attacks of herpetic } \\
\text { keratitis }\end{array}$} & \multirow{2}{*}{$\begin{array}{l}\text { Duration of symptoms } \\
\text { (days) }\end{array}$} & \multirow{2}{*}{$\begin{array}{l}\text { Extraocular herpetic } \\
\text { infections } \\
-\end{array}$} & \multirow{2}{*}{$\begin{array}{l}\text { Presence of accompanying } \\
\text { stromal reaction and/or } \\
\text { iritis }\end{array}$} \\
\hline 1 & $\mathbf{M}$ & 66 & & & & \\
\hline 2 & $\mathbf{M}$ & 67 & 1 & 70 & - & $\begin{array}{l}\text { Stromal reaction } \\
\text { Iritis }\end{array}$ \\
\hline 3 & $F$ & 49 & $\begin{array}{l}2 \\
\text { (in both eyes) }\end{array}$ & 20 & - & $\begin{array}{l}\text { Stromal reaction } \\
\text { Iritis }\end{array}$ \\
\hline 4 & $\mathbf{M}$ & 57 & - & 90 & + & $\begin{array}{l}\text { Stromal reaction } \\
\text { Iritis }\end{array}$ \\
\hline 5 & $\mathbf{M}$ & 82 & 1 & $4-5$ & - & $\begin{array}{l}\text { Stromal reaction } \\
\text { Iritis }\end{array}$ \\
\hline 6 & $\mathrm{~F}$ & 71 & 1 & 2 & + & - \\
\hline 7 & $\mathrm{~F}$ & 26 & $4-5$ & 6 & + & - \\
\hline
\end{tabular}

course. The clinical information on the patients is listed in Table 1A.

Two patients who suffered from fresh recurrent herpetic keratitis were followed and tears collected on days $2,5,9$ or $1,3,5$, and 15 after the first symptoms occurred. Five of the patients (nos. 1, 3, 4, 5 , and 6) had severely inflamed, red eyes, while 2 of them (nos. 2 and 7) had slightly inflamed eyes.

The group of controls was heterogeneous. Two healthy persons (nos. 9 and 10) with no signs of eye disease, and 5 persons (nos. 8,11,12,13, and 14) with lesions of nonherpetic origin in the eye, were selected (Table 1B). The reason for the heterogeneous control group was that we wanted to include controls with lesions that allowed leakage of serum proteins into the lacrimal fluid in order to test for the specificity of locally produced antibodies induced during infection with HSV-1.

\section{COLLECTION OF TEARS AND ESTIMATION OF}

\section{SERUM ALBUMIN}

Approximately $200 \mu \mathrm{l}$ tear fluid from both eyes of each patient was collected in $50 \mu \mathrm{l}$ capillary tubes.

Tear secretion was insufficient in many patients, and consequently the tear production was stimulated in order to collect enough lacrimal fluid.

Stimulation was performed by directing a jet of ice-cold air to the centre of the unaffected cornea. The air jet was made by a glass cone with an exit orifice of $1 \mathrm{~mm}$ and a flow of $1 \frac{1 / 2}{l}$ air per second. The cone was placed at a distance of $5 \mathrm{~cm}$ from the cornea. The rapid cooling of the cornea provoked sufficient reflex tearing in both eyes.

The tear fluid was drawn into capillary tubes from the lacrimal river at the lateral canthus by capillary action, and when filled, the tubes were sealed with wax and stored at $-70^{\circ} \mathrm{C}$ until use.

The content of serum albumin in tear fluid was measured in a micromodification of the electroimmunoassay of Prause. ${ }^{67}$

PREPARATION OF HSV-1 AND MOCK COATED DISCS VERO cells grown as monolayer cells in $75 \mathrm{~cm}^{2}$ tissue culture flasks with minimum essential medium (MEM) supplemented with $10 \%$ fetal calf serum, were infected with HSV-1 (F) at a multiplicity of 10 plaque-forming units per cell in a volume of $1.0 \mathrm{ml}$ MEM with $1 \%$ fetal calf serum. After $1 \mathrm{~h}$ of

Table 1B Controls

\begin{tabular}{|c|c|c|c|c|c|c|}
\hline \multicolumn{3}{|c|}{$\begin{array}{l}\text { Control no., } \\
\text { sex, age (years) }\end{array}$} & \multirow{2}{*}{$\begin{array}{l}\text { Clinical diagnosis } \\
\begin{array}{l}\text { Keratitis punctata } \\
\text { (caused by contact lens) }\end{array}\end{array}$} & \multirow{2}{*}{$\begin{array}{l}\text { Presence of } \\
\text { accompanying stromal } \\
\text { reaction and/or iritis }\end{array}$} & \multirow{2}{*}{$\begin{array}{l}\text { Presence of corneal } \\
\text { ulcer } \\
\text { Epithelial lesions }\end{array}$} & \multirow{2}{*}{$\begin{array}{l}\text { Extraocular herpetic } \\
\text { infections } \\
-\end{array}$} \\
\hline 8 & $\mathbf{F}$ & 25 & & & & \\
\hline 9 & $\mathbf{F}$ & 40 & Health person & - & - & - \\
\hline 10 & $F$ & 52 & Healthy person & - & - & - \\
\hline 11 & $\mathbf{F}$ & 65 & $\begin{array}{l}\text { Adenovirus } \\
\text { keratoconjunctivitis }\end{array}$ & - & Epithelial lesions & - \\
\hline 12 & $\mathbf{F}$ & 80 & $\begin{array}{l}\text { Corneal ulcer (due to } \\
\text { traumatic affection) }\end{array}$ & + & + & - \\
\hline 13 & $\mathbf{F}$ & 73 & Absolute glaucoma & + & Epithelial lesions & - \\
\hline 14 & $\mathbf{M}$ & 44 & $\begin{array}{l}\text { Dislocation of the lens } \\
\text { with glaucoma }\end{array}$ & + & Epithelial lesions & - \\
\hline
\end{tabular}


adsorption at $37^{\circ} \mathrm{C}$ the inoculum was aspirated and 10 $\mathrm{ml}$ MEM with $1 \%$ fetal calf serum was added. $18 \mathrm{~h}$ after infection, HSV-1 and uninfected (MOCK) cell extracts were prepared and bound to activated diazobenzyl-oxymethyl paper discs. ${ }^{8-10}$

\section{DETECTION OF HSV-1 SPECIFIC SECRETORY IgA}

IN LACRIMAL FLUID

The radioimmune assay in use has been detailed elsewhere. ${ }^{9}$ In order to measure secretory IgA, the IgG present in lacrimal fluid and in serum was removed by binding of the Fc-region of IgG to formalin-fixed staphylococcus carrying protein $\mathrm{A}$ on its surface (Cowan I strain). ${ }^{11}$ The preparation of fixed staphylococcus was made as described elsewhere and stored in a 5\% (v/v) suspension in PBS and 1\% $(\mathrm{w} / \mathrm{v})$ sodium azide. ${ }^{12}$

$50 \mu \mathrm{l}$ of lacrimal fluid was diluted with $50 \mu \mathrm{l}$ of a $0.05 \mathrm{M}$ Tris- $\mathrm{HCl}$ buffer pH 7.4 (with $0.15 \mathrm{M} \mathrm{NaCl}$, $0.05 \mathrm{M}$ EDTA, $0.25 \%(\mathrm{w} / \mathrm{v})$ gelatin, $0.05 \%(\mathrm{v} / \mathrm{v})$ Triton X-100, and $2 \%(w / v)(B S A)$ and incubated with staphylococcus pelleted from $0.66 \mathrm{ml}$ of a $5 \%$ suspension. After incubation for $1 / 2 \mathrm{~h}$ at $4^{\circ} \mathrm{C}$ the staphylococcus was removed by centriguation for 1 min at $12000 \mathrm{rpm}$ in a microcentrifuge (Rune, Germany).

$100 \mu \mathrm{l}$ of the IgG-depleted lacrimal fluid was incubated with $2 \%(\mathrm{v} / \mathrm{v})$ of rabbit antibodies $(\mathrm{IgG})$ to the secretory component of human $\operatorname{IgA}$ (antisecretory IgA) (DAKO, Copenhagen, Denmark). The incubation was done for $1 / 2 \mathrm{~h}$ at $4^{\circ} \mathrm{C} .50 \mu \mathrm{l}$ of the sample was incubated in microtitre plates (Nunc, Roskilde, Denmark) with either an HSV-1 or a MOCK disc for $4-5$ at $37^{\circ} \mathrm{C}$. The discs were washed extensively in the buffer detailed above, and then incubated with ${ }^{125} \mathrm{I}$ labelled protein A (specific activity $30 \mathrm{mCi} / \mathrm{mg}$; Amersham, England). ${ }^{910}$

The amount of ${ }^{125}$ I-labelled protein $\mathrm{A}$ bound to the discs was measured after extensive wash. The discs were counted in a $\gamma$-counter (Selectronic), and the specific binding was calculated as the difference between the binding to an HSV-1 disc and that to a MOCK disc. The specific binding of secretory IgA present in lacrimal fluid from patients and controls was measured relative to the maximum binding obtained by incubation of the paper discs with the saturating amount of HSV-specific serum IgG. This was obtained from a strongly reacting, seropositive donor, and the same reference serum was used throughout the study.

\section{DETECTION OF HSV-1 SPECIFIC IgG IN}

\section{LACRIMAL FLUID AND SERUM}

The content of HSV-1 specific IgG was measured in paired samples of lacrimal fluid and serum for all the persons selected for the present pilot study. The radioimmune assay with the discs was used as follows:

Lacrimal fluid was used unabsorbed and diluted 1:2 in the buffer. $50 \mu$ l of this dilution was incubated with either an HSV-1 disc or with a MOCK disc. The serum samples were diluted 1:10 before incubation with the HSV-1 and the MOCK discs, and $50 \mu \mathrm{l}$ samples were applied as described above. After incubation for $4-5 \mathrm{~h}$ at $37^{\circ} \mathrm{C}$ the discs were washed extensively and incubated with ${ }^{125}$ I-labelled protein A. ${ }^{910}$

The quantitation of the amount of specifically bound, iodinated protein $\mathrm{A}$ was done after extensive wash as described in the previous section. The specific binding of IgG was calculated as a percentage of the maximum binding obtained with the reference serum IgG from the HSV-1 seropositive donor.

\section{Results}

QUANTITATIVE ANALYSIS OF HSV-SPECIFIC SECRETORY IgA (SIgA) IN LACRIMAL FLUID Samples of lacrimal fluid from all patients and

Table 2 Herpes simplex virus specific secretory IgA in lacrimal fluid

\begin{tabular}{|c|c|c|c|c|c|c|c|c|c|}
\hline \multirow[t]{2}{*}{ Patient no. } & \multicolumn{4}{|c|}{$\begin{array}{l}{ }^{125} \text { I-labelled protein-A-bound } \\
\text { (counts per minute) }\end{array}$} & \multirow[t]{2}{*}{ Control no. } & \multicolumn{4}{|c|}{$\begin{array}{l}{ }^{125} \text { I-labelled protein- } A \text {-bound } \\
\text { (counts per minute) }\end{array}$} \\
\hline & $\begin{array}{l}\text { HSV }-1 \\
\text { protein }\end{array}$ & $\begin{array}{l}\text { MOCK } \\
\text { protein }\end{array}$ & $\begin{array}{l}\text { Specific } \\
\text { binding }\end{array}$ & $\begin{array}{l}\text { Percentage* } \\
\text { binding }\end{array}$ & & $\begin{array}{l}\text { HSV }-1 \\
\text { protein }\end{array}$ & $\begin{array}{l}\text { MOCK } \\
\text { protein }\end{array}$ & $\begin{array}{l}\text { Specific } \\
\text { binding }\end{array}$ & $\begin{array}{l}\text { Percentage* } \\
\text { binding }\end{array}$ \\
\hline $0^{\dagger}$ & 4550 & 469 & 4081 & 100 & & & & & \\
\hline 1 & 2633 & 223 & 2410 & $59 \cdot 5$ & 8 & 438 & 284 & 154 & $3 \cdot 8$ \\
\hline 2 & 2056 & 148 & 1908 & $46 \cdot 8$ & 9 & 379 & 268 & 111 & $2 \cdot 7$ \\
\hline 3 & 1871 & 67 & 1804 & $44 \cdot 2$ & 10 & 304 & 199 & 105 & $2 \cdot 6$ \\
\hline 4 & 1193 & 249 & 944 & $23 \cdot 1$ & 11 & 154 & 188 & -34 & 0 \\
\hline 5 & 2891 & 290 & 2601 & $63 \cdot 7$ & 12 & 238 & 256 & -18 & 0 \\
\hline 6 & 1553 & 249 & 1304 & $32 \cdot 0$ & 13 & 316 & 162 & 154 & $3 \cdot 8$ \\
\hline 7 & 870 & 199 & 671 & $16 \cdot 4$ & 14 & 153 & 77 & 76 & 1.9 \\
\hline
\end{tabular}

*Percentage binding was calculated as specific binding of the sample/specific binding of the reference $\times 100 \%$.

†Maximum binding obtained by incubation of the paper discs with saturating amount of HSV specific IgG. 


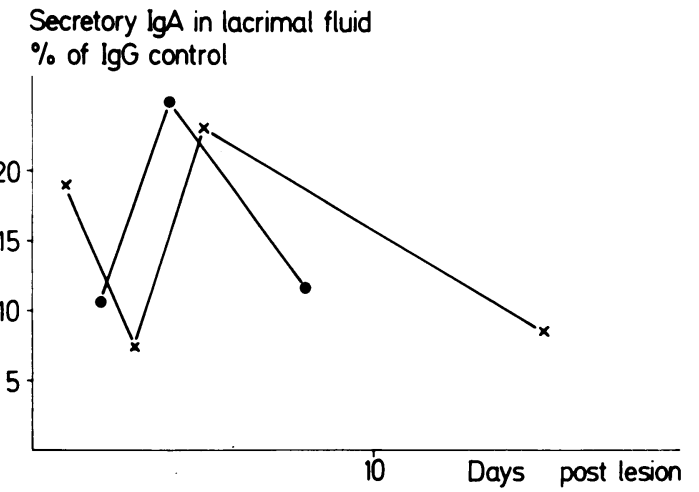

Fig. $1 H S V$-specific secretory IgA present in lacrimal fluid from 2 patients with fresh recurrent herpes keratitis. The patients were followed up for 9 days - and for 15 days $\times-\times$ respectively. Days post lesion were counted from when the first symptom of a corneal lesion appeared.

controls were analysed for the amount of HSVspecific SIgA, and the results are listed in Table 2.

The quantity of HSV-specific SIgA in lacrimal fluid from herpes keratitis patients varied between $16.4 \%$ and $63.7 \%$, whereas the amount of HSV-specific SIgA in the control group (nos. 8 to 14) was maximally $3.8 \%$ (Table 2 ). All the controls were negative for the specific secretory $\operatorname{IgA}$ in lacrimal fluid, though the control persons with eye lesions of nonherpetic origin (nos. 11 to 14) showed leakage of serum protein into the lacrimal fluid.

The specific SIgA was followed in 2 patients during the active phase of the keratitis. The patient followed up on days 3,5,9 and the one followed on days 1,3,5, and 15 had the maximal amount of SIgA in their tears between days 3 and 5 (Fig. 1).

QUANTITATIVE ANALYSIS OF HSV-SPECIFIC IgG

IN LACRIMAL FLUID AND IN SERUM

Paired samples of lacrimal fluid and serum from patients as well as from control persons were tested for the quantity of HSV-specific IgG measured in the radioimmune test.

The quantity of $\operatorname{IgG}$ in the lacrimal fluid from the affected eye from patients nos. 1-7 ranged from $14.8 \%$ to $36.8 \%$ of the maximal amount of IgG bound under saturating conditions. Among the controls only the lacrimal fluid from nos. 12,13, and 14 was positive for $\mathrm{IgG}$, and the amount was from $24 \cdot 2 \%$ to $55 \cdot 3 \%$. The lacrimal fluid from controls nos. 8-11 was negative for HSV-specific IgG (the maximum value was $2 \cdot 6 \%$ ). The controls nos. 12,13 , and 14 , who were positive for HSV-specific IgG in lacrimal fluid, had severely inflamed eyes, so that leakage of serum IgG into the lacrimal fluid could not be excluded. That leakage occurred was confirmed by the measurement of albumin in the lacrimal fluid as described below.

It should be mentioned that all persons selected for the present study except control no. 10 were positive for HSV-specific IgG in serum, and the quantity ranged from $10 \%$ to $100 \%$.

\section{ALBUMIN MEASURED IN PAIRED SAMPLES}

OF LACRIMAL FLUID AND SERUM

Detection of increased amounts of albumin in lacrimal fluid is an indicator of the impairment of blood vessels, which leads to passive diffusion of serum proteins into the lacrimal fluid. The amount of albumin in the lacrimal fluid of patients as well as controls is listed in Table 3. The normal value of albumin measured in lacrimal fluid from unaffected eyes is approximately 1 to $25 \mu \mathrm{g}$ per ml. ${ }^{13}$ The patients with severely inflamed, red eyes (nos. 3,4 , and 5) had increased amounts of albumin in the lacrimal fluid, with values ranging between 102 and $364 \mu \mathrm{g}$ per ml. (SI conversion: $\mu \mathrm{g} / \mathrm{ml} \times 1=\mathrm{mg} / \mathrm{l}$.) Patients nos. 2 and 7 did not have increased albumin $(23.6$ and 12.5 $\mu \mathrm{g} / \mathrm{ml}$ respectively), which was in agreement with the clinical findings, as these 2 patients had slightly inflamed eyes. The albumin concentration in tears from patients nos. 1 and 6 was not measured because of shortage of lacrimal fluid obtained.

Table 3 Albumin concentration in lacrimal fluid and in serum

\begin{tabular}{|c|c|c|c|c|c|}
\hline \multirow[t]{2}{*}{ Patient no. } & \multicolumn{2}{|l|}{ Albumin } & \multirow[t]{2}{*}{ Control no. } & \multicolumn{2}{|l|}{ Albumin } \\
\hline & $\begin{array}{l}\text { Lacrimal } \\
(\mu \mathrm{g} / \mathrm{ml})\end{array}$ & $\begin{array}{l}\text { Serum } \\
(\mathrm{mmol} / \mathrm{l})\end{array}$ & & $\begin{array}{l}\text { Lacrimal } \\
(\mu \mathrm{g} / \mathrm{ml})\end{array}$ & $\begin{array}{l}\text { Serum } \\
(\text { mmol } / \mathrm{l})\end{array}$ \\
\hline 1 & ND & 682 & 8 & $16 \cdot 6$ & 699 \\
\hline 2 & $23 \cdot 6$ & 600 & 9 & $45 \cdot 6$ & 675 \\
\hline 3 & 142.5 & 673 & 10 & $9 \cdot 9$ & 575 \\
\hline 4 & $364 \cdot 0$ & 668 & 11 & $16 \cdot 0$ & 610 \\
\hline 5 & $102 \cdot 0$ & 611 & 12 & $160)$ & ND \\
\hline 6 & ND & 549 & 13 & ND & 576 \\
\hline 7 & $12 \cdot 5$ & 663 & 14 & $86 \cdot 9$ & 662 \\
\hline
\end{tabular}

Normal range in lacrimal fluid: $1 \cdot 4-21.6 \mu \mathrm{g} / \mathrm{ml}$. (SI conversion: $\mu \mathrm{g} / \mathrm{ml} \times 1=\mathrm{mg} / \mathrm{l}$.) Normal range in serum: $532-813 \mathrm{mmol} / \mathrm{l}$. ND=not determined. 
Among the control persons, one with no sign of clinical eye disease (no. 10) also had albumin concentrations within the normal range. The other (control no. 9) showed an increase of albumin in the lacrimal fluid. This cannot be explained from the information available on this person. The controls with eye lesions of nonherpetic origin (nos. 11 to 14 ) had different degrees of leakage. The patients with ulcus cornea and with glaucoma showed increased levels of albumin in the lacrimal fluid (albumin was not measured for control no. 13 because of shortage of fluid), but the control with adenokeratoconjunctivitis maintained a normal concentration of albumin in the eye.

The concentration of serum albumin for all the patients and controls was within the normal range, from 532 to $813 \mathrm{mmol}$ per $\mathrm{ml}$ (Table 3).

\section{Discussion}

Secretory IgA plays a significant role for resistance to a variety of viral infections. Protection against infections with for instance entero-, myxo-, or paramyxovirus is directly correlated to the presence of secretory immunoglobulins, largely of the IgA class. ${ }^{414}$

Herpes simplex virus infections of the eye have previously been studied in both man and the rabbit. The production of herpes simplex-specific IgG and IgA was demonstrated in the lacrimal fluid during human eye infections. ${ }^{2}{ }^{15}$ The possible role of $\operatorname{IgA}$ for the protection against herpes simplex virus infections of the eye has received some attention, and the possibility that the effective neutralisation of infectious virus is dependent on the co-operative effect of both IgG and IgA has been discussed. ${ }^{16}$ The methods used have not allowed the detection of HSV-specific secretory $\operatorname{IgA}$, although this might represent the majority of the total IgA.

In the present study herpes-specific antibodies of the secretory IgA class were found in human tears during an active herpes keratitis. The quantity was increased up to 20 times above the background value present in lacrimal fluid from controls (Table 2).

It should be specifically noted that persons with severely inflamed eyes due to affections of nonherpetic origin (controls nos. 12, 13, and 14) were completely negative for HSV-specific SIgA in the lacrimal fluid, although leakage of serum proteins into the lacrimal fluid did occur (Table 3). Passive transmission of $\mathrm{HSV}$-specific IgG and IgA from serum into the lacrimal fluid was therefore possible. ${ }^{13}$ The finding that all patients and controls except no. 10 were positive for HSV-specific IgG in serum made the demonstration of HSV-specific IgG in the lacrimal fluid of no diagnostic value.
The conclusion that the immunoglobulin measured in the test was secretory IgA was possible only when the second antibody used in the test was directed specifically towards the secretory component of human IgA. ${ }^{17}$ That this was the case was demonstrated by the inability of the reagent to bind to the $\alpha$-chains of serum IgA.

In conclusion, the radioimmune assay allows the demonstration and quantitation of HSV-specific SIgA in lacrimal fluid from patients with active herpes keratitis. SIgA apparently reached a maximal amount within the first week of the disease (Fig. 1). Our results indicate that the SIgA represents locally produced antibodies made only during the active phase of the disease. The local production is supported by a few observations where tears from the healthy eye of herpes keratitis patients were collected and shown to be negative for HSV-specific SIgA (data not shown). The secretory IgA might thus be of diagnostic value for the herpes keratitis, but this has to be evaluated in a double-blind study where lacrimal fluid from a significant number of patients and controls is collected.

We are grateful to Carsten Juhl and Ruth Feldborg for their skilled technical assistance and to our colleagues at the Department for Tumour Biology, University of Copenhagen, for sharing equipment. Professor E. Gregersen, the Eye Clinic, Rigshospitalet, Copenhagen, has been involved in encouraging discussions.

The work was supported by Danish Medical Research Grant no. 512-2348. The Danish Foundation for the Advancement of Medical Science and the Carlsberg Foundation have supported purchase of equipment necessary for the work.

Bente Pedersen was supported by Danish Medical Research Grant no. 512-2348 and Dr Chen Zhong was a DANIDA trainee visiting from the Capital Medical College, Beijing, China.

\section{References}

1 Dawson CR, Togni B. Herpes simplex eye infections: clinical manifestations, pathogenesis and management. Surv Ophthalmol 1976; 21: 121-35.

2 Krichevskaya GI, Zaitseva NS, Kainarbaeva KA, Basova NN, Vinogradova VL. The use of a passive hemagglutination test (PHA) in the diagnosis of viral eye diseases. Albrecht von Graefes Arch Klin Ophthalmol 1980; 214: 239-44.

3 Jerry LM, Kunkel HG, Adams L. Stabilization of dissociable $\mathrm{IgA}_{2}$ proteins by secretory component. J Immunol 1972; 109: 275-83.

4 Franklin RM. Secretory IgA production in the lacrimal gland. In: O'Connor GR, ed. The Immunology of the Mucous Membranes. New York: Masson, 1980: 13-9.

5 McClellan BH, Whitney CR, Newman LI, Allansmith MR. Immunoglobulins in tears. Am J Ophthalmol 1976; 76: 89-101.

6 Prause JU. Immunoelectrophoretic determination of tear fluid proteins collected by the Schirmer I test. Acta Ophthalmol (Kbh) 1979; 57: 959-67.

7 Prause JU, Sjöström H, Norén OY, Josefson L. A micromodification of the electroimmunoassay. Anal Biochem 1978; 85: 564-71.

8 Alwine JC, Kemp DJ, Stark GR. Method for detection of specific RNAs in agarose gels by transfer to diazobenzyl-oxymethyl-paper and hybridization with DNA probes. Proc Natl Acad Sci USA $1977 ; 74: 5350-4$. 
9 Norrild B, Pedersen B, M $\phi$ ller-Andersen S. Herpes simplex virus specific secretory $\operatorname{IgA}$ in lacrimal fluid during herpes keratitis. Scand J Clin Lab Invest in press.

10 Norrild B, Pedersen B, Roizman B. Immunological reactivity of herpes simplex virus 1 and 2 polypeptides electrophoretically separated and transferred to DBM paper. Infect Immun $1981 ; 31$ : $660-7$.

11 Ratner JJ, Sanford BA, Smith KO. Use of protein A-treated sera in unmasking herpes simplex virus type 1 (HSV-1) immunoglobulin A and identifying HSV-1 immunoglobulin $\mathrm{G}$ as the predominant neutralizing antibody. J Clin Microbiol 1979; 10: 415-8.

12 Kessler SW. Rapid isolation of antigens from cells with a staphylococcus protein A-antibody adsorbent: parameters of the interaction of antibody-antigen complexes with protein A. $J$ Immunol 1975; 115: 1617-24.
13 Prause JU. Healing and repair in corneal tissues. The role of the polymorphonuclear leucocyte, in the cornea in health and disease. Royal Society Medical International Congress Symposium Series No. 40. London and New York: Academic Press, 1980.

14 Smith CB, Bellantini JA, Chanock RM. Immunoglobulins in serum and nasal seretions following infection with type 1 parainfluenza virus and infection of inactivated vaccines. $J$ Immunol 1967; 99: 133-41.

15 Little JM, Centifanto YM, Kaufman HE. Immunoglobulins in human tears. Am J Ophthalmol 1969; 68: 898-905.

16 Centifanto YM, Kaufman HE. Secretory immunoglobulin A and herpes keratitis. Infect Immun 1970; 2: 278-82.

17 Sapse AT, Bonavida B, Stone W, Sercarz EE. Proteins in human tears. I. Immunoelectrophoretic patterns. Arch Ophthalmol $1969 ; 81: 815-9$ 